\title{
Impact of some Heavy Metals pollutants in Lake Temsah in relation to Red tilapia, Egypt
}

Eissa I. A. M. ${ }^{1}$, Aly S. M. ${ }^{2}$, Marwa A. Hassan ${ }^{3}$, Esraa E. Eyada ${ }^{4}$

Depts. of Fish Diseases ${ }^{1}$, Pathology ${ }^{2}$ and Animal Hygiene, Zoonoses and

Behaviour ${ }^{3}$, Faculty of Vet. Medicine, Suez Canal University

Fish Farming and Technology Institute ${ }^{4}$, Suez Canal University.

\begin{abstract}
:
The present study aimed to investigate the type and degree of water pollution in Lake Temsah. Then, studying the effect of most recorded heavy metals on fish and role of garlic in improving the health status of exposed Red Tilapia .The results during the field survey revealed higher level of lead followed by cupper then iron with no cadmium record. A total number of 165 Red Tilapia fish were equally distributed into five groups each with a triplicate of 11 fish. Lead acetate was added to tank's water of all groups of experiment except the control group. Garlic was added and used as a treatment to selected groups. The groups exposed to Lead acetate only revealed decrease in the RBCs, $\mathrm{Hb} \%$, HCT with increase in MCV and MCH and MCHC in the $3^{\text {rd }}$ and $6^{\text {th }}$ weeks of the feeding experiment. In addition, leukocytopenia, neutrophilia, lymphopenia with elevation in serum creatinine, ALT, AST in comparison with control group. When garlic added during the feeding experiment, an increase in the survival and significant increase in growth and weight-gain were seen in all treated groups beside significant improvement in the blood parameters and indices. It is concluded that, Garlic at dose $0.25 \mathrm{~g} / \mathrm{kg}$ eliminated partially Lead toxicity from the fish body, which in turn improved the growth and immunity.
\end{abstract}

Key words: Heavy metals, Garlic, Red Tilapia, Serum Biochemistry, Hematology, Histopathology.

\section{Introduction}

Due to the insufficiency of protein origins for the vast increased population in the third human beings area, fish farming has gained popularity as alternative source of a cheap protein (Zeitoun and Mehana, 2014).

In last decades, world fish consumption has increased at the same time as its nutritional and therapeutic benefits are increasingly concerned. Marine fish are preferable than freshwater fish, as the former are rich in trace elements such as phosphorus and iodine for cell metabolism. Besides its important source of protein, fish typically contain high levels of essential minerals, vitamins and 
unsaturated fatty acids (Eissa et al., 2012)

Water is the most renewable resource on our planet and is crucial for modern technology to survive and develop. Rapid industrialization is therefore one of the major causes of water pollution. Treated sewage has been used for fish raising in various regions of the world (Ashraf, 2005). Several catastrophes have occurred due to the accumulation of heavy metals in fish, for example, the Minamata poisoning in Japan has caused neurological damage and death to people who consume fish contaminated with organic mercury (Cariccio et al., 2018) .

In the recent years, Lake Temsah has attracted increasing attention. It plays an important role in most of Ismailia City's activities, is an important economic resource and is considered the backbone of the tourism industry, which attracts a large number of holiday visitors (Kaiser et al., 2009).

Heavy metals are natural trace components of the aquatic environment, but they have increased due to industrial waste, geochemical structure, farming and mining. All these pollution sources have an impact on the physiochemical characteristics of water, sediments and also biological components, affecting the quality and quantity of fish stocks. Environmental pollution is a global problem; heavy metals are one of the biggest polluting challenges. The industry's progress has resulted in increased pollutant emissions into the ecosystem (Zeitoun and Mehana, 2014).

For thousands of years, Garlic (Allium sativum), a hard and enduring bulb originating in the Mediterranean regions of Africa and Europe, has been attributed to incredible medicinal power. It has a beneficial effect in preventing adverse effects on heavy metals. Garlic compounds have been reported to have massive antioxidant properties that use reactive oxygen species (ROS), enhancing cellular antioxidant enzymes that prevent cell damage / death (Doreswamy, 2008).

The main objectives of this study were to analyzing water samples from Lake Temsah for detecting heavy metals with experimental studies to determine the toxic effects of Lead $(\mathrm{Pb})$ with and without garlic on Red Tilapia through hematological, serum biochemical, gross and histopathology examinations as well as determination of tissue residues.

\section{Materials and Methods}

1. Field studies on Lake Temsah:

Seventy-two water samples were collected under aseptic conditions from six localities of Lake Temsah 1- Sherkt El-Temsah 2- El-Shouraa 3- El-Taawn 4-El-Nours 5- ElFayrouz 6- The Bridge. They were 
collected during the period from January 2016 to December 2016.

A dry, clean crew capped polyethylene bottles of $2 \mathrm{~L}$. capacity were used for the collection of samples. The chemical analysis of heavy metals in marine water was done according to Brooks et al. (1967) by using atomic absorption spectrophotometer (Thermoelectron Corporation, types S4 A A sys.) according to Price (1972) .

\section{The experimental Design:}

A total number of (165) fish was equally distributed into 5 groups each of 33 fish with a triplicate of 11 fish per fiberglass tank to determine the impact of Lead acetate on Red tilapia which exceed the permissible limit of WHO (2004) and Egyptian Chemical Standard (1994). The Lead dose was calculated by the average of maximum levels found in the survey. The conc of Lead acetate to the water tank was calculated by the following equation:

ppm of element $=\frac{\text { Molecular weight of salts }}{\text { Molecular mass of the element }} \mathrm{X}$ required Conc of elements By dissolving $0.47 \mathrm{~g} \backslash \mathrm{l}$ and $2.35 \mathrm{gll}$ lead acetate, a final conc of $0.3 \mathrm{ppm}$ $\left(\begin{array}{ll}1 & \mathrm{x}\end{array}\right)$ and $1.5 \mathrm{ppm}(5 \mathrm{x})$ lead respectively were obtained.

Lead acetate was added to tanks water of some groups in the experiment and Garlic powder was added to the pellet and used as a treatment to some groups in the experiment. The groups were divided as the following:
Group (1) was the control received basal diet. Group (2) fish received basal diet with a lead dose $(0.3$ ppm) added to tank's water. Group (3) received basal diet mixed with garlic with dose $(0.25 \mathrm{~g} / \mathrm{kg})$ according to Abdelazeem et al. (2012) and lead was added at dose of $(0.3 \mathrm{ppm})$ to tank's water. Group (4) fish received basal diet without garlic and a lead dose (1.5 ppm) was added to tanks' water. Group (5) was fish received basal diet with garlic $(0.25 \mathrm{~g} / \mathrm{kg})$ and lead dose (1.5 ppm) was added to tank's water.

Preparation of garlic Pellets (Diets):

A balanced ration in the form of pellets was obtained from (AQUA) International for Food Industries. Egg white was mixed with garlic powder at a dose of $0.25 \mathrm{~g} / \mathrm{kg}$ and added gradually to the previously formulated pellets to assure the homogensity of the ingredients. Batches of feed were prepared every two weeks and pellets left for $24 \mathrm{hr}$ to air dry, and stored in a refrigerator $\left(4^{\circ} \mathrm{C}\right)$ for daily use.

Determination of fish body weight and total length:

The body weight and total length of the examined fish was recorded separately before dissecting to avoid any fluid or tissue losses using electronic balance for measuring body weight and ruler for measuring total length.

Clinical and Postmortem examinations: 
All fish samples were clinically examined according to the method described by Amlacher (1970) for detecting any abnormalities. The fish samples (Oreochromis sp.) were collected alive from Fish Farming and Technology Institute. The post-mortem examination was carried out on all freshly dead and moribund fish to demonstrate internal abnormalities according to Conroy and Hermann (1981). Hematological analysis:

Blood was collected by heart puncture of the fish using heparinized syringe in vials containing ethylene diamine tetra acetic acid (EDTA), which was used to estimate hematological parameters. The sampled fish were then killed immediately by the concussive blow to the head of each selected fish and placed on the ice to perform the morphometric measurements of each of fish. The mean length of the fish $(10 \pm 3 \mathrm{~cm})$ and the mean weight $(25 \pm 5 \mathrm{~g})$. Healthy checks of similar length and body weight have been bought from the nearby fish farm. The RBCs count was made by Neubauer hemocytometer (Shah and Altindag, 2004) Blood was diluted 1:200 with Hayem's solution. Erythrocytes were counted in the loaded hemocytometer chamber and total numbers were reported as $10^{6}$ $\mathrm{mm}^{3}$ (Wintrobe, 1967).

Hemoglobin was estimated in blood by using cyanmethemoglobin method described by Wintrobe
(1967). Hematocrit value ( $\mathrm{Ht} \%)$ was determined by using small haematocrit graduated tubes and hematocrit centrifuge at $3000 \mathrm{rpm}$ for 10 minutes. Mean Corpuscular Volume (MCV), Mean Corpuscular Hemoglobin (MCH) and Mean Corpuscular Hemoglobin Concentration (MCHC) were calculated according to Baker and Silverton (2014).

WBCs count was made by Neubauer hemocytometer Shah and Altinda ğ (2005). Blood was diluted 1:20 with Turk's diluting fluid and placed in haemocytometer. Four large $(1 \mathrm{sq} \mathrm{mm})$ corner squares of the hemocytometer were counted under the microscope. The cells touching the boundary lines were not counted. The total number of WBC was calculated in $\mathrm{mm}^{3} \times 10^{3}$ Wintrobe (1967). The blood smears were prepared and stained with Giemsa stain for 30 minute. One hundred leukocytes were identified and the percentage values of different white cells were calculated according to Jain (1986).

\section{Serum analysis:}

Serum aspartate amino transferase (AST) and alanine amino transferase (ALT) activities were determined colorimetrically using transferases kits according to method described by Reitman and Frankel (1957). Creatinine was determined by Jaffe spectrophotometric method described by Pratt ( 1996) and Aitken et al. (2003). 
Determination of Lead residues on Red Tilapia Fish:

Red Tilapia Fish were collected to obtain samples from musculature was subjected to digestion, filtration, storage and measured by Atomic absorption spectrophotometer (Thermoelectron Corporation, types S4 A A sys.) according to Clowely (1978).

Histopathological Examination:

A tissue specimen from different organs of Red Tilapia fish (liver, gills and musculature) were collected and immediately fixed in $10 \%$ neutral buffered formalin for 48 hours to one week. Processing was done routinely and tissue slides stained by routine hematoxylin and eosin (H\&E) according to Carleton et al. (1980).

Statistical Analysis: -

Obtained results were statistically analyzed using spss version 16 computer program (INC. 19892010) to show least significant difference (LSD) by F. test (ANOVA test) at significant levels ranged between ( $\mathrm{P} \leq 0.08)$ to ( $\mathrm{P} \leq 0.01)$.

\section{Results}

I. Results of field studies water sampling (survey from Lake Temsah):

The minimum, maximum and mean values of tested heavy metals in Lake Temsah during four seasons from January 2016 to December 2016 in comparison with the permissible limits of $\mathrm{WHO}$ and the International Egyptian Chemical standard 1994 were recorded in Table (1).

\section{Result of experimental} studies:

A. The growth parameters at $6^{\text {th }}$ week (Weight and Length) of experiment were shown in Table (2).

\section{B. Clinical signs:}

The external examination was performed on Red tilapia (Oreochromis sp.) where the exposed fish groups showed nervous manifestations as sluggish movement, darkening of the skin, erosion in tail with thickened mucus over the body and gills.

\section{Hematological and Serum biochemical parameters:}

The hematological and serum biochemical parameters at $6^{\text {th }}$ week of experiment were reported in Tables (3\&4).

\section{Postmortem examination} of Red Tilapia after 6 weeks of feeding experiment:

1. Group 1 (control):

Group 1, Red tilapia revealed normal morphological appearance without any PM changes or pathognomonic lesions seen in the internal organs. Group 2 and 4, hemorrhage and congestion at the base of the fins and congestion on liver, kidney and gills were evident. Group 3 and 5, showed normal external and internal appearance. 
E. Results of Muscle digestion at $3^{\text {rd }}$ and $6^{\text {th }}$ week of the experiment (Table 5):

At the $3^{\text {rd }}$ week of the experiment, there was a significant increase in Lead acetate $(\mathrm{Pb})$ deposition level $(9.97 \mathrm{mg} / \mathrm{kg})$ in the musculature of Group (4) that received 5x Average of lead without garlic compared to $6.58 \mathrm{mg} / \mathrm{kg}$ for Group (2) that received Average lead without garlic, Group (5) (5x Average of lead with garlic) showed 5.97 $\mathrm{mg} / \mathrm{kg}$ in the musculature of fish compared with Group (3) that received Average lead with Garlic (3.52 mg/kg) and control Group (1) Lead $(\mathrm{Pb})$ was not detected in the Musculature during the feeding experiment. Similar results were shown at $6^{\text {th }}$ week of the experiment.

\section{F. Histopathology studies:}

Group (1) control: revealed no marked tissue reaction with normal cellular details and cellular architecture for each gill, hepatopancreas and musculature. Group 2 and 4 Gills reveled severe congestion and hemorrhage in the gill arch and primary as well as secondary gill lamellae which exhibited focal epithelial desquamation. Hepatopancreas showed marked congestion in the hepatic and pancreatic vessels with focal hemorrhage and necrosis in both hepatocytes and pancreatic acinar cells. Some mononuclear leukocytes were seen infiltrating the necrotic cells. Musculature displayed intermuscular edema and focal hyaline degeneration as well as Zenker's necrosis. The necrotic musculature was invaded by some mononuclear cells and melanomacrophage cells (Photos 13). Group 3 and 5, Gills showed congestion in the gill arch and focal mononuclear and melanomacrophage cell infiltration in the gill lamellae. Hepatopancreas revealed mild parenchymal edema and vacuolar degeneration of some hepatocytes and pancreatic acinar cells. Musculature exhibited proliferation of mononuclear infiltration cells between the muscle bundles

(Photos 4-6). 
Table (1): Detection of some heavy metals from Lake Temsah during four seasons of 2016 in comparison to WHO and Egyptian Chemical Standards (Mean \pm SE).

\begin{tabular}{|c|c|c|c|c|c|c|}
\hline \multirow{2}{*}{$\begin{array}{l}\text { Heavy } \\
\text { metals }\end{array}$} & \multirow{2}{*}{ Season } & \multirow{2}{*}{$\begin{array}{c}\text { Mean } \pm \\
\text { Standard error }\end{array}$} & \multirow{2}{*}{ Minimum } & \multirow{2}{*}{ Maximum } & \multicolumn{2}{|c|}{ Permissible limits } \\
\hline & & & & & $\begin{array}{c}\text { WHO } \\
(2004) \\
\text { Ppm }\end{array}$ & $\begin{array}{c}\text { Egyptian } \\
\text { Chemical } \\
\text { Standards } \\
\text { (1994) ppm }\end{array}$ \\
\hline \multirow[t]{4}{*}{ Copper } & Winter & $0.823 \pm 0.053$ & 0.7 & 1 & \multirow[t]{4}{*}{2} & \multirow[t]{4}{*}{1} \\
\hline & Spring & $0.777 \pm 0.067$ & 0.52 & 1.02 & & \\
\hline & Summer & $0.9 \pm 0.085$ & 0.69 & 1.22 & & \\
\hline & Autumn & $0.845 \pm 0.075$ & 0.55 & 1.06 & & \\
\hline \multirow[t]{4}{*}{ Lead } & Winter & $0.243 \pm 0.015$ & 0.19 & 0.3 & \multirow[t]{4}{*}{0.01} & \multirow[t]{4}{*}{0.05} \\
\hline & Spring & $0.148^{*} \pm 0.015$ & 0.11 & 0.22 & & \\
\hline & Summer & $0.2566 \pm 0.051$ & 0.08 & 0.4 & & \\
\hline & Autumn & $0.316^{*} \pm 0.035$ & 0.17 & 0.42 & & \\
\hline \multirow[t]{4}{*}{ Iron } & Winter & $0.052 \pm 0.011$ & 0.01 & 0.08 & \multirow[t]{4}{*}{0.2} & \multirow[t]{4}{*}{1} \\
\hline & Spring & $0.025 \pm 0.008$ & 0 & 0.06 & & \\
\hline & Summer & $0.049 \pm 0.015$ & 0 & 0.11 & & \\
\hline & Autumn & $0.084 \pm 0.024$ & 0 & 0.17 & & \\
\hline \multirow[t]{4}{*}{ Cadmium } & Winter & ND & ND & ND & \multirow[t]{4}{*}{0.005} & \multirow[t]{4}{*}{0.01} \\
\hline & Spring & ND & ND & ND & & \\
\hline & Summer & ND & ND & ND & & \\
\hline & Autumn & ND & ND & ND & & \\
\hline
\end{tabular}

Table (2): showing Weight and length of different groups of Red Tilapia at $6^{\text {th }}$ week post-experiment (Mean $\pm \mathrm{SE}$ ).

\begin{tabular}{|c|c|c|c|c|c|}
\hline & Group (1) & Group (2) & Group (3) & Group(4) & Group (5) \\
\hline Length & $10.58 \pm$ & $\mathbf{9 . 8 0} \pm 2.00$ & $10.65 \pm$ & $10.2 \pm 2.01$ & $9.92 \pm 2.71$ \\
(cm) & 5.42 & & 2.24 & & \\
\hline Weight (g) & $21.56 \pm$ & $18.5 \pm$ & $24.47 \pm$ & $22.42 \pm 1.34$ & $23.12 \pm 2.32$ \\
& 1.29 & 1.171 & 1.62 & & \\
\hline
\end{tabular}

Group (1) = Control, Group (2) = low dose of Lead 0.3 ppm without Garlic, Group (3) = low dose of Lead 0.3 ppm with Garlic, Group (4) = high dose of Lead1.5 ppm without Garlic, Group (5) = high dose of Lead 1.5 ppm with Garlic 
Table (3): Hematological parameters of different groups of Red Tilapia at $6^{\text {th }}$ week post-experiment (Mean $\pm \mathrm{SE})$.

\begin{tabular}{|c|c|c|c|c|c|}
\hline & Group (1) & Group (2) & Group (3) & Group(4) & Group (5) \\
\hline $\mathbf{H b}$ & $5.05 \pm 0.45$ & $4.75 \pm 0.25$ & $5.1 \pm 0.2$ & $5 \pm 0.2$ & $5.65 \pm \mathbf{0 . 4 5}$ \\
\hline HCT $^{* *}$, a & $22.5^{a} \pm 3.7$ & $16.2^{\mathrm{ab}} \pm 0.3$ & $15.3^{b} \pm 0.6$ & $15^{b} \pm 0.6$ & $16.3^{\mathrm{ab}} \pm 2.7$ \\
\hline $\operatorname{RBCs} \Delta$ & $1.8 \pm 0$ & $1.55^{b} \pm 0.05$ & $1.65^{\mathrm{ab}} \pm 0.05$ & $1.65^{\mathrm{ab}} \pm 0.05$ & $1.95^{a} \pm 0.25$ \\
\hline MCV & $93.1 \pm 2.4$ & $109 \pm 5.65$ & $103 \pm 10.95$ & $103 \pm 11.25$ & $93.7 \pm 1.8$ \\
\hline МCH & $33.4 \pm 3.4$ & $36.25 \pm 1.85$ & $34.45 \pm 3.65$ & $34.35 \pm 3.75$ & $33.7 \pm 3.1$ \\
\hline МСНC $\Delta$ & $32.7^{b} \pm 0.4$ & $33.3^{a} \pm 0$ & $33.3^{a} \pm 0$ & $33.3^{a} \pm 0$ & $33.3^{a} \pm 0$ \\
\hline WBCs* & $5.15^{\mathrm{ab}} \pm 0.35$ & $5.6^{\mathrm{ab}} \pm 0.95$ & $5.95^{a} \pm 0.95$ & $3.5 \mathrm{~b} \pm 0.5$ & $4.3^{\mathrm{ab}} \pm 0.7$ \\
\hline $\mathbf{N} \operatorname{seg} * * *$ & $32^{b} \pm 2$ & $33.5^{\mathrm{ab}} \pm 1.5$ & $32^{b} \pm 2$ & $34.5^{\mathrm{ab}} \pm 0.5$ & $32.5^{\mathrm{ab}} \pm 2.5$ \\
\hline $\mathrm{N}$ band & $4 \pm 1$ & $3 \pm 0$ & $3 \pm 0$ & $4.5 \pm 0.5$ & $4 \pm 1$ \\
\hline Lymphocytes & $50 \pm 0$ & $52 \pm 0$ & $47 \pm 5$ & $50.5 \pm 0.5$ & $53 \pm 2$ \\
\hline Monocytes & $8 \pm 1$ & $9 \pm 1$ & $8 \pm 0$ & $8.5 \pm 0.5$ & $7.5 \pm 0.5$ \\
\hline Eosinophils & $3.5 \pm 0.5$ & $3.5 \pm 1.5$ & $3.5 \pm 1.5$ & $2 \pm 0$ & $2.5 \pm 0.5$ \\
\hline
\end{tabular}

. The mean difference is significant at the 0.05 level, .**The mean difference is significant at the 0.06 level, .***The mean difference is significant at the 0.07 level, . SThe mean difference is significant at the 0.08 level, athere was a significant decrease in all treated groups as compared to control at 0.1 levels.

Table (4): Serum biochemical parameters of different groups of Red Tilapia at $6^{\text {th }}$ weeks post-experiment (Mean $\left.\pm S E\right)$.

\begin{tabular}{|c|c|c|c|c|c|}
\hline & Group (1) & Group (2) & Group (3) & Group(4) & Group (5) \\
\hline Creatinine & $0.4^{b} \pm 0.1$ & $2.25^{\mathrm{ab}} \pm 1.75$ & $1.85^{b} \pm 1.45$ & $1.65^{\mathrm{ab}} \pm 1.25$ & $0.45^{b} \pm 0.05$ \\
\hline ALT* & $12.7^{b} \pm 1.7$ & $19.6^{\mathrm{ab}} \pm 7.4$ & $24.65^{b} \pm 4.35$ & $22.5^{\mathrm{ab}} \pm 0.5$ & $33.0{ }^{a} \pm 7$ \\
\hline AST* & $12.95^{c} \pm 3.25$ & $14.5^{c} \pm 3.5$ & $29^{a b} \pm 1$ & $24.5^{b c} \pm 5.5$ & $40.0^{a} \pm 5$ \\
\hline
\end{tabular}

*The mean difference is significant at the 0.05 level.

Table (5): Digestion of Musculature of Red Tilapia and the levels of Lead $(\mathrm{Pb})$ in each group at $3^{\text {rd }}$ and $6^{\text {th }}$ week of the feeding experiment $(\mathrm{ND}$, not detected):

\begin{tabular}{|l|c|c|}
\hline \multicolumn{1}{|c|}{ Groups } & $\begin{array}{c}\text { Concentration of Lead } \\
\text { in musculature at } 3^{\text {rd }} \\
\text { week }(\mathrm{mg} / \mathrm{kg})\end{array}$ & $\begin{array}{c}\text { Concentration of Lead } \\
\text { in musculature at } 6^{\text {th }} \\
\text { week }(\mathrm{mg} / \mathrm{kg})\end{array}$ \\
\hline Group 1 (control) & $\mathrm{ND}$ & ND \\
\hline Group 2 (low dose of Lead $0.3 \mathrm{ppm}$ without garlic) & 6.58 & 6.28 \\
\hline Group 3 (low dose of Lead 0.3 ppm with garlic) & 3.52 & 3.69 \\
\hline Group 4 (high dose of Lead 1.5 ppm without garlic) & 9.97 & 13.98 \\
\hline Group 5 (high dose of Lead 1.5 ppm with garlic) & 5.97 & 5.11 \\
\hline
\end{tabular}



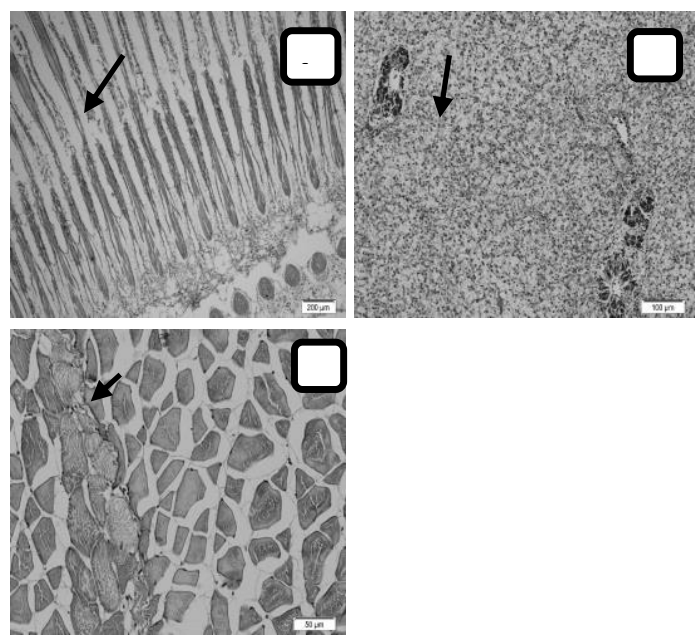

Photo (1): Gills showing sloughing of the secondary gill lamellae with edema and mononuclear cells infiltration in both arches and lamellae. H\&E stain, $\mathrm{x} 100$.

Photo (2): Hepatopancreas showing parenchymal edema and focal vacoulation of hepatocytes and pancreatic acinar cells. H\&E stain, x 100. Photo (3): Musculature showing intermuscular edema and focal hyaline degeneration as well as Zenker's necrosis with some mononuclear cells. H\&E stain, $x 250$.
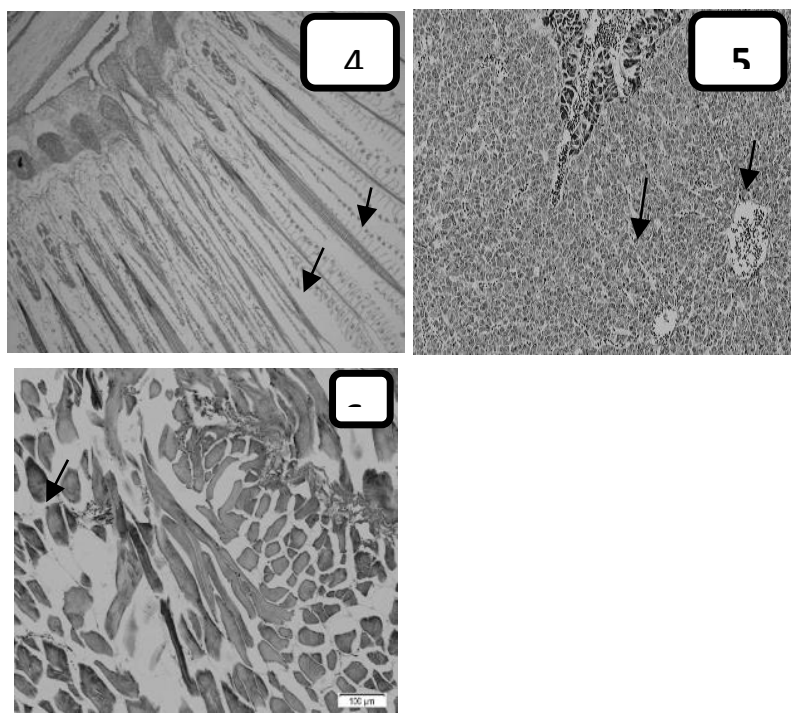

Photo (4): Gills showing edema in gill arch and secondary gill lamellae with congestion in the secondary lamellae and some mononuclear cells infiltration. H\&E stain, x 100. 
Photo (5): Hepatopancreas showing congestion and vacuolar degeneration of hepatocytes. H\&E stain, $x 100$.

Photo (6): Musculature showing focal infiltration of mononuclear infiltration cells between the muscle bundles that exhibited intermuscular edema and focal hyaline degeneration. H\&E stain, $x 250$.

\section{Discussion}

The field survey reported the results of tested heavy metals concentrations $(\mathrm{Pb}>\mathrm{Cu}>\mathrm{Fe}>\mathrm{Cd})$ in the water samples collected from different localities in Lake Temsah: (1- Sherkt El-Temsah 2- El-Shouraa 3- El-Taawn 4-El Nours 5- ElFayrouz 6- The bridge). The detected results were in agreement with Abdel-Shafy (1995) who recorded the heavy metals concentration in Lake Temsah $(\mathrm{Pb}$, $\mathrm{Zn}, \mathrm{Cu}$ and $\mathrm{Cd}$ ), they found lead was the highest element in compare to cadmium that was the lowest concentration.

The elevated level of Lead in water samples; might attributed to the presence of industrial discharge superphosphate factories. Since this area is the most densely populated and there are, many industrial effluents and wastes were discharged to the lake water. Van Dam and Pauly (1995) stated the high way or motor boat traffic is the main source of Lead pollution. Also, El Nabawi et al. (1987) reported that, the industrial and agriculture discharge are primary source of lead pollution in Egypt.

Lead showed the more prevalent heavy metals during the four seasons of the study year with minimum value $0.11 \mathrm{PPM}$ during spring and Maximum 0.42 PPM during autumn. The heavy metals in the autumn were the significant higher level while the lead values were the significant lower in the spring season. The mean of concentration within the permissible limits guideline values for water quality from the WHO (2004) for lead $(0.01 \mathrm{ppm})$. According to Egyptian Chemical Standards (1994), the maximum permissible limit of heavy metals in surface water is $0.05 \mathrm{mg} / \mathrm{l}$ for $\mathrm{Pb}$, while those Guideline values for water quality from the World Health Organization WHO (1994) for lead is $0.05 \mathrm{ppm}$. According to National Academy of Science (1973) the safe concentration of lead in water were ranging from 0.00059 to 0.0059 ppm. Also, Fresenius et al. (1988) mentioned the safe concentration for lead in healthy water was 0.05 ppm. The comparison between our results and the earlier recommended international standards indicated a higher Lead concentration recorded in all water samples collected from the 6 localities in Lake Tesmah.

This mean concentration of Cadmium was within the permissible limit guideline values for water quality according the 
WHO (2004) (0.005 ppm). According to Egyptian Chemical Standards (1994) the maximum permissible limits of heavy metal in surface water of $(\mathrm{Cd})$ was $(0.01$ $\mathrm{mg} / \mathrm{l})$.

The data obtained revealed the lowest concentrations of cadmium (Cd) in the tested water samples throughout the year. This result is in covenant with El-Din and El-Hak (2017) who studied the heavy metal concentration in lake Temsah water and reported high concentrations of iron $(\mathrm{Fe})$ and lowest concentrations for cadmium $(\mathrm{Cd})$. Lead $(\mathrm{Pb})$ is a pervasive and persistent environmental pollutant that can be detected in almost all phases of environment and biological systems. Both waterborne and trophic exposures can lead to a significant accumulation of this metal in distinct fish tissues, leading to different consequences to physiological processes as well as reduced food safety of fish Dai et al. (2009). Therefore, a potentially safe therapeutic approach to reduce lead accumulation in food animals would have very important healthrelated consequences.

Although the current therapeutic approach to lead toxicity is to increase the excretion of lead by chelation, the safety and efficacy of the various chelators may be questioned Ahamed and Siddiqui (2007).

According to several reports, Garlic (Allium sativum) has an important dietary and medicinal role for centuries. It has also recognized since ancient times as a flavoring agent for food. The suggested pharmacological effects of garlic are hypolipidemic, hypoglycemic, anticoagulant, antihypertensive, antimicrobial, anticancer and antitumor, antioxidant, as an antidote for heavy metal poisoning, hepatoprotective, and as an immunomodulatory (Das and Saha, 2009).

All above-mentioned pharmacological and therapeutic benefits of garlic, that support our choice as an antitoxic against lead toxicity.

Regarding the growth parameters, the fish exposed to heavy metal showed significant decrease in body weight and body weight gain during the feeding experiment as compared to control group. There is some evidence that addition of garlic in diet significantly improves body weight and body weight gain as compared to control group. The reduction of feed conversion rate in Red Tilapia might be due the tissue burden of more heavy metals, which in turn could cause reduction food intake, and poor food conversion efficiency. These results are in consistent with that of $\mathbf{A b d e l}$ Tawwab and Wafeek (2010) and Abdel-Tawwab et al. (2008).

The external examination was performed on Red Tilapia (Oreochromis sp.) that were collected from each group during the period of experiment, the control group revealed no 
pathognomic clinical signs, in the other groups some fish showed nervous manifestations as sluggish movement, darkening of the skin, erosion in tail with thickened mucus over the body and gills. This signs similar to those previously reported Sorensen (1991).

About the hematological and histopathological alteration along the feeding experiment in the groups that exposed to lead acetate without Garlic. Our data exhibit decrease in hemoglobin concentration (HB \%), HCT and total erythrocyte count during the $3^{\text {rd }}$ and $6^{\text {th }}$ weeks till the end of feeding experiment in Group 2 and Group 4. These results are supported by Zaghloul et al. (2005). Ghazaly (1991) showed a reduction in $\mathrm{RBC}$ and $\mathrm{Hb}$ in Tilapia zillii exposed to $8.3 \mathrm{mg} / \mathrm{l}$ of $\mathrm{Pb}$. In addition to Allen (1993) who also stated a decrease in $\mathrm{RBC}, \mathrm{Hb}$ and $\mathrm{Ht}$ in Oreochromis aureus treated with $10 \mathrm{mg} / \mathrm{l}$ of $\mathrm{Pb}$.

This accredited to reduction in red blood corpuscles production in the hematopoietic organs under the damage effect of massive heavy metals concentrations recorded in water samples. Such reduction might also cause by the intrahepatic and intra-splenic hemorrhage induced by the action of accumulated heavy metals and decrease oxygen intake due to the damaged gills. Moreover, this explanations broadly supported by the histopathological alterations in gills, musculature and the liver. That includes marked congestion in the hepatic and pancreatic vessels with focal hemorrhage and necrosis in both hepatocytes and pancreatic acinar cells.

The anemic conditions in fish may be detected using hematocrit (Adakole, 2012). The PCV values always decrease when a fish loses appetite or become diseased or stressed. At present, the distinct decrease in the level of Hemoglobin and PCV was noticed after exposure to heavy metals, iron clearly suggests a haemodilution mechanism possibly due to gill damage or impaired osmoregulation. The haemodilution has been interpreted as a mechanism that reduces the concentration of the irritating factor in the circulatory system.

Leukocytopenia reported in the present study especially in the groups exposed to Lead Acetate during the feeding experiment in comparison with control group, this is in agreement with Witeska (2005).

In the present study, there was a significant increase in lymphocyte counts in the Group (2) and Group (4). The groups which feed on Garlic showed significant decrease in lymphocyte and decreased neutrophil as compared to other groups. The observed result not agree with Arias et al. (2004) and Tavares-Dias and Faustino (1998) reported that, in stressful situations, 
the number of circulating lymphocytes decreases and the percentages of neutrophils increased. Sampath et al. (1998) observed that neutrophil increase in fish exposed to $0.1,0.3$ and 0.6 $\mathrm{mg} / \mathrm{L} \mathrm{Cu}$ or $\mathrm{Zn}$ for 50 days. Kosai et al. (2011) reported that leukocytes counts increased in lead exposure as compare those of the control group and neutrophil showed greatest sensitivity to changes in the environment and were the most important of the leucocytes. Chronic exposure of fishes to sublethal levels of metals caused damage to various tissues.

On the other hand, in our study results revealed that administration of Garlic induced significant increase in all blood parameters (erythrocyte count, leukocyte count and hemoglobin content), which agrees with the results of Martins $\boldsymbol{e t}$ al. (2002), who verified that addition of $A$. sativum to fish diets increased erythrocytes number, leukocyte count and hemoglobin content. The reversal of haematotoxic effect of lead nitrate in mice is not very clear. However, the antioxidative and protective role of $A$. sativum may be suggested to be implicated.

Serum Creatinine, ALT and AST activities used in diagnosis of damage fish tissues (i.e. gill, muscle, liver) De la Torre et al. (2000). Determinations of transaminases (AST and ALT) have been useful in the diagnosis of liver and kidney diseases in fish Maita (1984).

In our results, an increase in creatinine in groups exposed to Lead acetate in comparison with the control group in the first 3 weeks till the end of the feeding experiment was seen, this is in agreement with Lockhart and Metner (1984) who reported that, Elevated serum creatinine and uric acid levels can be used as indicators of kidney dysfunction.

In Group (2) and Group (4), ALT and AST showed significant increase during feeding experiment, this is in agreement with Heath (1995) who reported that Cell injury of certain organs leads to the release of tissue-specific enzymes into the blood stream. The significant $(\mathrm{P}<$ 0.05 ) increased of transaminases (AST and ALT) activity in fish exposed to heavy metals may reveal possible leakage of enzymes across damaged plasma membranes and/or the increased synthesis of enzymes by the liver. The histopathological alternation obtained in hepatic parenchyma in the present study confirmed the aforementioned high levels of activities of both serum AST \& ALT. where, the liver revealed wide spread necrosis of hepatocytes in all hepatic lobules along with marked intercellular edema, vascular thrombosis and perivascular fibrosis.

On the other hand, the groups that feed on Garlic diets showed significant decrease in creatinine as compared with control group during 
feeding experiment creatinine showed slightly significant decrease. This is in agreement with Eidi et al. (2006) who showed the decrease in serum creatinine on rats after oral administration of garlic extract $(0.1,0.25$ and $0.5 \mathrm{~g} / \mathrm{kg}$ body wt.) for 14 days.

ALT and AST showed significant increase in the groups treated with Garlic supplement as compared with control group during feeding experiment, contrary with Shalaby et al. (2006) who found that serum AST and ALT activities decreased significantly in the fish group fed on all levels of Allium sativum and chloramphenicol.

Table (6) revealed that, Garlic significantly decreased heavy metal bioaccumulation in group (3) and group (5) as compared to other groups during feeding experiment. This is in agreement with May et al. (2012) who revealed that garlic significantly decreased heavy metal bioaccumulation in supplemented group as compared to nonsupplemented group for $\mathrm{Cd}, \mathrm{Pb}, \mathrm{Cu}$ and $\mathrm{Zn}$. Doreswamy et al. (2004) observed decreased metal content of tissues resulting from Allium sativum componenets interaction with copper and zinc in some ways to prevent its deposition in tissues.

\section{References}

ABDEL-SHAFY, H. I and AbdelSabour A. 1995. Levels of heavy metals in the environment of river Nile and some Egyptian surface water German Egyptian conference, Ismailia, 6-7, February, pp36-53.

ABDEL-TAWWAB, M., ABDELRAHMAN, A. M. \& ISMAEL, N. E. 2008. Evaluation of commercial live bakers' yeast, Saccharomyces cerevisiae as a growth and immunity promoter for Fry Nile tilapia, Oreochromis niloticus (L.) challenged in situ with Aeromonas hydrophila. Aquaculture, 280, 185189.

ABDEL-TAWWAB, M. \& WAFEEK, M. 2010. Response of Nile tilapia, Oreochromis niloticus (L.) to environmental cadmium toxicity during organic selenium supplementation. Journal of the World Aquaculture Society, 41, 106-114.

ABDELAZEEM, M., HASSAN, A. M., HUSSEIN, M. M., H ABDELWAHED, Z. \& SALEH, R. 2012. Some Heavy Metal Pollutants in Fish Farms and Effect of Garlic on Their Bioaccumulation in Oreochromas niloticus.

ADAKOLE, J. 2012. Changes in some haematological parameters of the African catfish (Clarias gariepinus) exposed to a metal finishing company effluent. Indian Journal of Science and Technology, 5, 2510-2514.

AHAMED, M. \& SIDDIQUI, M. K. J. 2007. Environmental lead toxicity and nutritional factors. Clinical Nutrition, 26, 400-408.

AITKEN, M., HALL, E., SCOTT, L., DAVOT, J. \& ALLEN, W. 2003. Liver-related biochemical 
changes in the serum of dogs being treated with phenobarbitone. The Veterinary Record, 153, 13-16.

ALLEN, P. 1993. Effects of acute exposure to cadmium(II) chloride and lead(II) chloride on the haematological profile of Oreochromis aureus(Steindachner). Comparative Biochemistry and Physiology, C, 105, 213-217.

AMLACHER, E. 1970. Testbook of Fish Disease. P.117-135. T.F.H. Publication, Neptune, USA

ARIAS, C., WELKER, T., SHOEMAKER, C., ABERNATHY, J. \& KLESIUS, P. 2004. Genetic fingerprinting of Flavobacterium columnare isolates from cultured fish. Journal of Applied Microbiology, 97, 421-428.

ASHRAF, W. 2005. Accumulation of heavy metals in kidney and heart tissues of Epinephelus microdon fish from the Arabian Gulf. Environmental Monitoring and Assessment, 101, 311-316.

BAKER, F. J. \& SILVERTON, R. E. 2014. Introduction to medical laboratory technology, ButterworthHeinemann.

BROOKS, R. R., PRESLEY, B. J. \& KAPLAN, I. R. 1967. APDCMIBK extraction system for the determination of trace elements in saline waters by atomic-absorption spectrophotometry. Talanta, 14, 809-816.

CARICCIO, V. L., SAMA, A., BRAMANTI, P. \& MAZZON, E. 2018. Mercury Involvement in Neuronal Damage and in Neurodegenerative
Biological trace element research, 1-16.

CARLETON, H. M., DRURY, R. A. B. \& WALlington, E. A. 1980. Carleton's histological technique, Oxford University Press, USA.

CLOWELY, K. M. 1978. Atomic absorption a development is food analysis in kind RD(1978): Science Publisher I T D Ripple - Rood borkind essexengland. .

CONROY, D. \& HERMANN, L. 1981. Textbook of fish diseases. TFH Publ., West Sylvania.

DAI, W., DU, H., FU, L., JIN, C., XU, Z. \& LIU, H. 2009. Effects of dietary $\mathrm{Pb}$ on accumulation, histopathology, and digestive enzyme activities in the digestive system of tilapia (Oreochromis niloticus). Biological trace element research, 127, 124-131.

DAS, I. \& SAHA, T. 2009. Effect of garlic on lipid peroxidation and antioxidation enzymes in DMBAinduced skin carcinoma. Nutrition, 25, 459-471.

DE LA TORRE, F., SALIBIAN, A. \& FERRARI, L. 2000. Biomarkers assessment in juvenile Cyprinus carpio exposed to waterborne cadmium. Environmental Pollution, 109, 277-282.

DORESWAMY, K., SHRILATHA, B. \& RAJESHKUMAR, T. 2004. Nickel-induced oxidative stress in testis of mice: evidence of DNA damage and genotoxic effects. Journal of andrology, 25, 996-1003. DORESWAMY, K. S., B.; RAJESHKUMAR, T. AND 
MURALIDHARA,A. 2008. Nickel induced oxidative stress in testis of Mice: Evidence of DNA damage and Genotoxic effects. J. Androl., 25: 996-1003.

EGYPTIAN CHEMICAL STANDARDS, E. 1994. Protection of the Nile River and Water Stream from pollution, Ministry of Irrigation, Cairo, Egypt, Law No 4. Cited by Badr M.A.et al ,.(2014). EIDI, A., EIDI, M. \& ESMAEILI, E. 2006. Antidiabetic effect of garlic (Allium sativum L.) in normal and streptozotocin-induced diabetic rats. Phytomedicine, 13, 624-629.

EISSA, I., EL-LAMIE, M. \& ZAKAI, M. 2012. Studies on Crustacean Diseases of Seabass, Morone Labrax, in Suez Canal, Ismailia Governorate. Life Science journal, 9.

EL-DIN, M. I. S. \& EL-HAK, H. N. G. 2017. IMPACT OF HEAVY METALS CONTAMINATION ON SPRING ABUNDANCE OF AQUATIC MACROINVERTEBRATES INHABITING LAKE TIMSAH, EGYPT. Journal of Water Security, 3.

EL NABAWI, A., HEINZOW, B. \& KRUSE, H. 1987. As, $\mathrm{Cd}, \mathrm{Cu}$, $\mathrm{Pb}, \mathrm{Hg}$, and $\mathrm{Zn}$ in fish from the Alexandria region, Egypt. Bulletin of Environmental Contamination and Toxicology, 39, 889-897.

FRESENIUS, W., QUENTIN, K. E. \& SCHNEIDER, W. 1988. Water analysis; a practical guide to physico-chemical, chemical and microbiological water examination and quality assurance, SpringerVerlag.

GHAZALY, K. 1991. Influences of thiamin on lead intoxication, lead deposition in tissues and lead hematological responses of Tilapia zillii. Comparative biochemistry and physiology. C, Comparative pharmacology and toxicology, 100, 417-421.

HEATH, A. G. 1995. Water Pollution and Fish Physiology. CRC. Press. Inc. Boca Raton, Florida. 359pp.

JAIN, N. C. 1986. Schalm's veterinary hematology, Lea \& Febiger.

KAISER, M., AMIN, A. \& ABOULELA, H. 2009. Environmental hazards in the ElTemsah Lake, Suez Canal District, Egypt. Advances in Geoscience and Remote Sensing. InTech.

KOSAI, JIRAUNGKOORSKUL, SYNSATAYAKUL, P., JIRAUNGKOORSKUL, K. 2011. Efficacy of calcium reducing lead toxicity in hematology of Oreochromis niloticus-. Journal of Fisheries and Aquatic Science, 6, 346-355.

LOCKHART, W. \& METNER, D. 1984. Fish serum chemistry as a pathology tool. Contaminant Effects on Fisheries, John Wiley and Sons, New York, New York 1984., 73-85. MAITA M, S. K. A. I. Y. 1984. Health Assessment by the Climogram of Hemochemical 
Constituents in Cultured Yellowtail. Bull. Jap. Soc. Scient. Fish. 51:205211.

MARTINS, M., MORAES, F., MIYAZAKI, D., BRUM, C., ONAKA, E., FENERICK, J. J. \& BOZZO, F. 2002. Alternative treatment for Anacanthorus penilabiatus (Monogenea: Dactylogyridae) infection in cultivated pacu, Piaractus mesopotamicus (Osteichthyes: Characidae) in Brazil and its haematological effects. Parasite, 9, 175-180.

MAY, H., HASSAN, A., HUSSEIN, M., ZAMZAM, H. \& SALEH, R. 2012. Some heavy metal pollutants in fish farms and Effect of garlic on their bioaccumulation in Oreochromas niloticus.

NATIONAL ACADEMY OF SCIENCE, N. 1973. Annual Report No. 9, p. 213.

PRATT, P. W. 1996. Laboratory Procedures for Veterinary Techniques. 3rd Edn, Mosby, Philadelphia. 98-99.

PRICE, W. J. 1972. analytical absorption spectrophotometer. Henyden, Son, London [Online].

REITMAN, S. \& FRANKEL, S. 1957. A colorimetric method for the determination of serum glutamic oxalacetic and glutamic pyruvic transaminases. American journal of clinical pathology, 28, 56-63.

SAMPATH, R., GALLAGHER, P. J. \& PAVALKO, F. M. 1998. Cytoskeletal Interactions with the Leukocyte Integrin $\beta 2$ Cytoplasmic
Tail ACTIVATION-DEPENDENT REGULATION OF ASSOCIATIONS WITH TALIN AND $\alpha$-ACTININ. Journal of Biological Chemistry, 273, 3358833594.

SHAH, S. \& ALTINDAG, A. 2004. Hematological parameters of tench (Tinca tinca L.) after acute and chronic exposure to lethal and sublethal mercury treatments. Bulletin of environmental contamination and toxicology, 73, 911-918.

SHAH, S. L. \& ALTINDAĞ, A. 2005. Alterations in the immunological parameters of Tench (Tinca tinca L. 1758) after acute and chronic exposure to lethal and sublethal treatments with mercury, cadmium and lead. Turkish Journal of Veterinary and Animal Sciences, 29, 1163-1168.

SHALABY, A., KHATTAB, Y. \& ABDEL RAHMAN, A. 2006. Effects of Garlic (Alliumsativum) and chloramphenicol on growth performance, physiological parameters and survival of Nile tilapia (Oreochromis niloticus). Journal of Venomous Animals and Toxins including Tropical Diseases, 12, 172-201.

SORENSEN, E. M. 1991. Metal poisoning in fish, CRC press.

TAVARES-DIAS, M. \& FAUSTINO, C. 1998. Parametros hematologicos da tipapia do Nilo Oreochromis niloticus Cichilidae em cultivo extensivo. Arq veterinária, 14, 254-272. 
VAN DAM, A. \& PAULY, D. 1995. Simulation of the effects of oxygen on food consumption and growth of Nile tilapia, Oreochromis niloticus (L.). Aquaculture Research, 26, 427-440.

WHO 2004. Guidelines for drinking-water quality: recommendations, World Health Organization.

WINTROBE, M. Clinical hematology (6th Eds.) Lea and Febiger, Philadelphia. Library of Congress, Print USA, 1967.

WITESKA, M. 2005. Stress in fishhematological and immunological effects of heavy metals. Electronic Journal of Ichthyology, 1, 35-41.
ZAGHLOUL, K., OMAR, W. \& ABO-HEGAB, $\mathrm{S}$. 2005. Environmental hazard risk assessment on Oreochromis niloticus and Tilapia zilli fsh. $J$. Egypt. Ger. Soc. Zool, 46, 105-139. ZEITOUN, M. M. \& MEHANA, E. 2014. Impact of water pollution with heavy metals on fish health: overview and updates. Global Veterinaria, 12, 219-231.

$$
\text { الملحص العربي }
$$

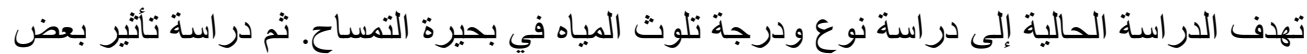

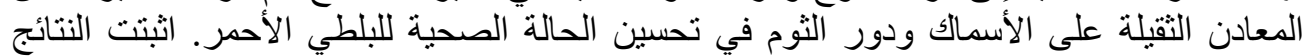

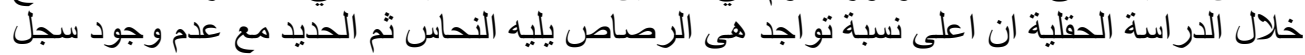

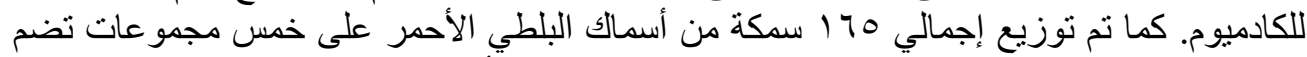

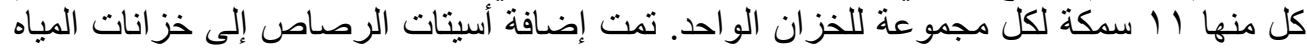

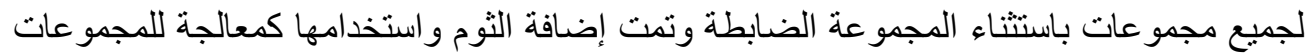

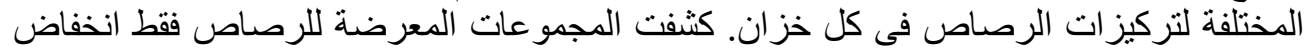

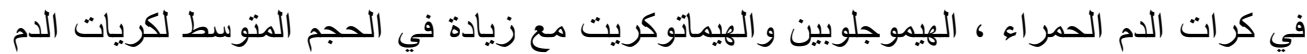

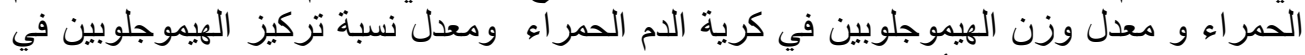

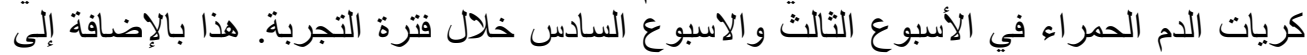

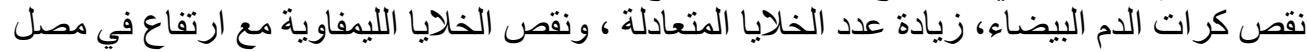

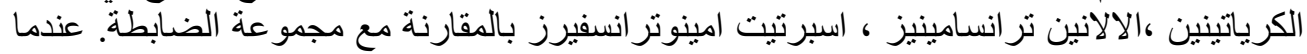

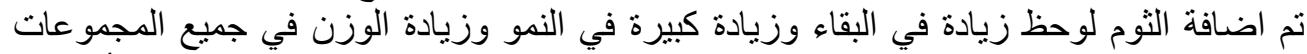

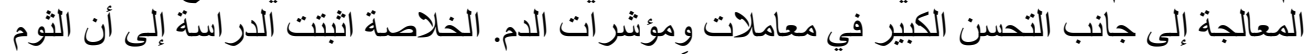

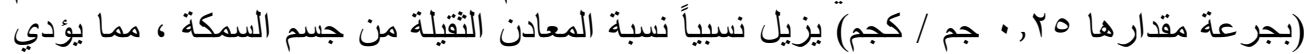
بدوره إلى تحسين نمو أسماك البلطي الأحمر.

الكلمات الافتتاحية: المعادن الثقيلة ، الثوم ، البلطي الأحمر ، الكيمياء الحيوية للمصل ، أمر اض الدم ، التشريح. 